O. V. ANDRUKHOVA ${ }^{1}$, Senior Lecturer, o.gavina@mail.ru

S. V. RAZMANOVA2, Chief Researcher, Doctor of Economic Sciences, Associate Professor

I. I. VOLKOVA ${ }^{1}$, Head of Department of Higher Mathematics, Candidate of Technical Sciences, Associate Professor

1 Ukhta State Technical University, Ukhta, Russia

2Ukhta's Gazprom VNIIGAZ Office, Ukhta, Russia

\title{
COMPARATIVE EVALUATION METHODS FOR TECHNOLOGIES IN OILFIELD SERVICES
}

\section{Introduction}

The present-day basic criteria of oilfield project selection by subsoil users are the Net Present Value (NPV) of investment and the Oil Recovery Factor (ORF) [1]. At the same time, technology as a project component is often missed in this case, while the optimal technologies can expose a range of various scenarios of mineral extraction from subsoil. For another thing, the calculation of NPV and ORF is not always a sufficient basis for making appropriate design solutions and selecting specific service providers. John McCreery (partner in Bain \& Company's Singapore Office) in his research says that high investment in corporate support can help companies whittle down expenses in case they are assumed as indicators of advanced experience in the industry and not as money. Similarly, technologies and services are indicators of the scientific and technical development in the industry. For this reason, decision-making on using a technology should not only consider expenses and affected profits of a subsoil user [2]. The authors think the "key criteria in selection of a contractor should be efficiency of technology and equipment; moreover, the economic expediency of introduction of technologies and equipment in oil services is to be evident for a service receiver and not short-term (i.e. dependent on the current prices and taxes at the time of commencement of the contract)" [3].

The Government of the Russian Federation enacted Decree No. 1458 on Dec 23, 2014 (as amended on Mar 9, 2019) to approve the Regulations on identification of the best available technology, as well as on development, updating and publication of resource books of the best available technologies [4]. The Regulations revise formulation of assessment criteria for processes, equipment, methods and means to be assumed as the best available in case of compliance with a set of such criteria. These criteria include the least environmental impact per time unit; the economic efficiency of introduction and operation; the use of resourceand energy-saving techniques; the introduction period; the commercialization of technologies, equipment, methods and means at two and more objects exerting negative impact on the environment in the Russian Federation. The mentioned document states that an efficient technology should take into account ecological aspects and be based on resource- and energy-saving methods.

The objective of this study is to shape an algorithm for the differentiated selection of technologies in oilfield services. Namely, the task is to identify significant criteria and their specific weight for the competitive technologies of oilfield service companies with the intention of valuing applicability of these technologies in the main operating and production processes of oil producing companies. Thus, a subsoil user, in the conditions of bidding, having received the actual data on application of a technology in terms of specific parameters, can calculate the total (integral) performance indicator of this technology and to compare it with similar technologies of the bidders. This method is advantageous for the simplicity and efficiency.

The Russian market of oilfield services is mostly represented by oil well drilling (more than 50\%) [5]. In the opinion of Aquaterra Energy's experts, with professional service providers and the best available technologies, drilling can ensure a strong basis for oil projects for the decades-long operation in the oil and gas industry [6]. The most important service segments in drilling are drilling fluid and well casing. Drilling fluids are used in any oilfield development as a range of various problems is solved in this case - starting from fluid flow rates to critical safety standards. The high-priority drilling fluids are intended for penetration into an active reservoir. The significant factor of well casing is grouting. The least percentage in the oilfield service structure in Russia belongs to the methods 
of oil recovery enhancement (8\%). The tertiary (modern) techniques of enhanced oil recovery (EOR) are of critical importance in reserve replacement. Thus, the present authors' choice of the oilfield service segments of drilling fluids, grouts and tertiary EOR is governed by their high significance for oilfield service companies.

He studies in the sphere of drilling fluids, well casing [7, 8] and EOR [9], as well as the advices of experts from the Ukhta State Technical University, Ukhta's Division of Gazprom VNIIGAZ and PechorNIPIneft, Ukhta's Division of LUKOIL-ENGINEERING, allowed systematizing general and partial criteria of technologies per types of oilfield services.

The use of the expert experience in assigning specific weights is one of the approaches to solving the problem on weights of criteria in technological decision-making by subsoil users and service companies taking part in bidding. This is a heuristic approach. A critical feature of an expert survey is its focus on a specific audience-high-skilled professionals in the specified areas of research. In view of the audience specificity, the basic method of the survey is not an interview but a questionnaire to be filled by an expert [10].

\section{Research methodology}

Data acquisition and sampling

This research aims to find relevant information on criteria of specific technologies at hand of oilfield service companies in the areas of drilling fluids, well casing and enhanced oil recovery. Based on the representative sampling of data on the criteria, the express-method is developed to evaluate technologies and innovations during bidding.

Professor Litvak in his research [11] sets the optimal size of an expert team as 5-7 (maximum 10-15) persons for face-to-face poll and 20-30 (maximum 60-80) for questioning in absentia. On the other hand, Professor Shlyapentokh believes that determination of an expert team size is an extremely difficult problem, and its solution is a heuristic function of researchers [10]. The expert survey respondents were highly skilled professionals. There are many such professionals inside the Timan-Pechora Hydrocarbon Province. The size of the expert team in this research is limited based on the criterion of integrative competence of an expert. This criterion of selecting exerts describes the available theoretical knowledge, know-how and hands-on experience necessary for an expert for the objective estimation of indicators in the preset domain of the questionnaire.

The integrative competence of an expert can be determined using Table 1.

The survey involved fellows and officers of research institutions and oil-producing companies in the Northwestern Federal District of Russia. Final sampling included 10 experts. The questionnaires were filled by the selected experts both in presence and in absentia due to the geographical farness of some experts. Personal interview of the fellows and officers (heads and specialists) of R\&D and educational bodies was carried out on a no-name basis. The use of expert estimates and expert opinions in various areas of science is obligatory for development of new testing procedures [12].

\section{Research tools}

The result of the expert survey were proceed using recommendations by I. I. Volkova [13], studies by G. L. Gromyko and E. V. Sidorenko [14, 15], and guidelines by S. S. Bondarchuk and I. S. Bodnarchuk [16].

The questioning data interpretation used Spearman's rank correlation coefficient for testing adequacy of matrices of the obtained values, Cochran's Q tests of experts' estimates and criteria and Kendall's coefficient of concordance of experts' opinions (Table 2).

One of the objectives of processing the expert survey results is identification of single-type experts. G. F. Romashkina and G. G. Tatrova [17] name this process the recovery of latent true ordering. In this case, the test of concordance between the experts' opinions is the next step of the Q-date processing. This procedure uses Kendall's W coefficient of concordance for repeated ranks [14]:

$$
W=\frac{12 S}{m^{2}\left(n^{3}-n\right)-m \sum_{1}^{m}\left(t^{3}-t\right)},
$$

where $S$ is the sum of squared deviations of summed ranks $m$ from mean rank; $m$ is the number of experts; $e$ is the number of the same ranks in each criterion.

If the hypothesis on concordance of the experts' opinions is confirmed, the averaged ranking is obtained using a median value or an arithmetic mean [17]. Kendall's W is calculated using the algorithm described in [14].

The Q-date processing results are compiled in Table 2.

The calculation of Spearman's rank correlation coefficient per each type of oilfield service allows judging on adequacy of the formed matrices (see table 2).

The research revealed the adequacy of the expert estimates for the further tests using Kendall's coefficient of concordance (W) [16]. The calculations failed to confirm the hypothesis on equality of dispersions in terms of partial criteria of drilling fluids, as well as general and partial criteria of EOR (semi-bold in Table 2). This means that the expert whose estimates show the highest dispersion should be withdrawn, and 
Table 2. Output data of expert estimates processing by mathematical statistics methods

\begin{tabular}{|c|c|c|c|c|c|c|}
\hline \multirow{2}{*}{\multicolumn{2}{|c|}{ Oilfield service }} & \multicolumn{5}{|c|}{ Matrices } \\
\hline & & \multicolumn{2}{|c|}{ General criteria } & \multicolumn{3}{|c|}{ Partial criteria } \\
\hline \multicolumn{7}{|c|}{ Spearman's rank correlation coefficient } \\
\hline \multicolumn{2}{|c|}{ Drilling fluid } & \multicolumn{2}{|c|}{0.88} & \multicolumn{3}{|c|}{0.81} \\
\hline \multicolumn{2}{|l|}{ Grout } & \multicolumn{2}{|c|}{0.93} & \multicolumn{3}{|c|}{0.896} \\
\hline \multicolumn{2}{|l|}{ EOR } & \multicolumn{2}{|c|}{0.90} & \multicolumn{3}{|c|}{0.91} \\
\hline \multicolumn{7}{|c|}{ Initial Cochran's Q test values for experts } \\
\hline & & $\mathrm{G}_{\text {calc }}$ & $\mathrm{G}_{\text {critical }}$ & $\mathrm{G}_{\text {calc }}$ & $\mathrm{G}_{\text {critical }}$ & $\mathrm{G}_{\text {critical }}$ \\
\hline Drilling flui & & 0.309 & 0.373 & 0.323 & 0.282 & 0.282 \\
\hline Grout & & 0.299 & 0.331 & 0.272 & 0.282 & 0.282 \\
\hline EOR & & 0.420 & 0.331 & 0.283 & 0.244 & 0.244 \\
\hline \multicolumn{7}{|c|}{ Adjusted Cochran's Q test values for experts } \\
\hline & & $\mathrm{G}_{\text {calc }}$ & $\mathrm{G}_{\text {critical }}$ & $\mathrm{G}_{\text {calc }}$ & $\mathrm{G}_{\text {critical }}$ & $\mathrm{G}_{\text {critical }}$ \\
\hline Drilling flui & & 0.309 & 0.373 & 0.2097 & 0.336 & 0.336 \\
\hline Grout & & 0.299 & 0.331 & 0.272 & 0.282 & 0.282 \\
\hline EOR & & 0.193 & 0.358 & 0.225 & 0.266 & 0.266 \\
\hline \multicolumn{7}{|c|}{ Cochran's Q test values for criteria } \\
\hline & & $\mathrm{G}_{\text {calc }}$ & $\mathrm{G}_{\text {critical }}$ & $\mathrm{G}_{\text {calc }}$ & $\mathrm{G}_{\text {critical }}$ & $\mathrm{G}_{\text {critical }}$ \\
\hline Drilling flui & & 0.49 & 0.50 & 0.24 & 0.35 & 0.35 \\
\hline Grout & & 0.32 & 0.42 & 0.29 & 0.33 & 0.33 \\
\hline EOR & & 0.35 & 0.44 & 0.21 & 0.25 & 0.25 \\
\hline \multicolumn{7}{|c|}{ Kendall's W and its check using Pearson's correlation coefficient } \\
\hline & W & $x^{2}$ calc. & $x^{2}$ tabl. & W & $x^{2}$ calc. & $x^{2}$ tabl. \\
\hline Drilling fluid & 0.2 & 15.19 & 7.81 & 0.3 & 23.15 & 12.59 \\
\hline Grout & 0.5 & 34.94 & 9.49 & 0.4 & 35.01 & 12.59 \\
\hline EOR & 0.7 & 39.71 & 9.49 & 0.4 & 36.87 & 16.92 \\
\hline
\end{tabular}

the test procedure should be repeated. Thus, by the matrix of the partial criteria of drilling fluid, the number of experts reduced by 2 and made 8 persons; by the matrix of the general and partial criteria of EOR, the number of experts made 9 persons. The calculations (See Table 2) prove the validity of the condition that $\mathrm{G}_{\text {calc }}<\mathrm{G}_{\text {critical }}$-the adjusted number of experts is assumed for the further research.

The adequacy of the criteria is checked in the same way, with regard to the adjusted number of experts.

Thus, the calculation of the concordance between exerts' opinions show a weak though significant correlation between the experts.

\section{Research results}

Based on the research outcome, Table $\mathbf{3}$ gives the specific weights of the criteria.

Some conclusions are drawn from the calculated median values of the experts' estimates per each row of criteria. The significant general criteria of drilling fluids include: drilling rate, problems in the course of drilling and drilling, cost dependent on the two former indicators. This characterizes mostly the effect exerted by the general criteria of drilling fluid service in accordance with their functional purpose, i.e. drilling-in, on the financial component of the production and economic efficiency of a subsoil user. In the opinion of the experts interrogated, the most significant partial criteria of drilling fluids aim at the preservation of properties of active reservoirs: porosity and permeability, cutting-carrying stability, stability
Table 3. Questionnaire list and specific weights of criteria

\begin{tabular}{|c|c|}
\hline Criterion & $\begin{array}{l}\text { Specific } \\
\text { weight } \\
\text { (median) }\end{array}$ \\
\hline \multicolumn{2}{|l|}{ General criteria of drilling fluids } \\
\hline $\begin{array}{l}\text { 1. Drilling rate } \\
\text { 2. Drilling problems } \\
\text { 3. Cost per } 1 \mathrm{~m} \text { drilling } \\
\text { 4. Environmental setting }\end{array}$ & $\begin{array}{l}0.25 \\
0.25 \\
0.25 \\
0.15\end{array}$ \\
\hline \multicolumn{2}{|l|}{ Partial criteria of drilling fluids } \\
\hline $\begin{array}{l}\text { 1. Porosity\&permeability preservation in reservoir } \\
\text { during drilling-in } \\
\text { 2. Cutting-carrying capacity } \\
\text { 3. Fluid survivability in reservoir conditions } \\
\text { 4. Stability of rocks in well } \\
\text { 5. Compliance with well clean-out requirements } \\
\text { 6. Increase in flow coefficient of porous medium } \\
\text { 7. Fluid flow rate cost }\end{array}$ & $\begin{array}{c}0.2 \\
0.2 \\
0.15 \\
0.2 \\
0.1 \\
0.1 \\
0.1\end{array}$ \\
\hline \multicolumn{2}{|l|}{ General criteria of grout } \\
\hline $\begin{array}{l}\text { 1. Formation segregation } \\
\text { 2. Grouting quality } \\
\text { 3. Problems (sticking. jamming. adhering) } \\
\text { 4. Environmental impact (toxicity rate) } \\
\text { 5. Drilling cost }\end{array}$ & $\begin{array}{l}0.3 \\
0.3 \\
0.2 \\
0.1 \\
0.1\end{array}$ \\
\hline \multicolumn{2}{|l|}{ Partial criteria of grouting } \\
\hline $\begin{array}{l}\text { 1. Interlocking with casing string and rocks } \\
\text { 2. Stability under higher temperatures and pressure } \\
\text { in well } \\
\text { 3. Sedimentation absence } \\
\text { 4. Yielding } \\
\text { 5. Pumping ability } \\
\text { 6. Resistance to scouring action of groundwater } \\
\text { 7. Drillability }\end{array}$ & $\begin{array}{c}0.2 \\
0.2 \\
0.125 \\
0.1 \\
0.1 \\
0.1 \\
0.1\end{array}$ \\
\hline \multicolumn{2}{|l|}{ General criteria of EOR } \\
\hline $\begin{array}{l}\text { 1. Change in oil production } \\
\text { 2. EOR effective time } \\
\text { 3. EOR duration } \\
\text { 4. Change in water cut } \\
\text { 5. EOR cost }\end{array}$ & $\begin{array}{l}0.3 \\
0.3 \\
0.1 \\
0.1 \\
0.1\end{array}$ \\
\hline \multicolumn{2}{|l|}{ Partial criteria of EOR } \\
\hline $\begin{array}{l}\text { 1. Effect on low-permeable blind zones } \\
\text { 2. Oil recovery factor } \\
\text { 3. Oil viscosity reduction } \\
\text { 4. Associated water recovery } \\
\text { 5. Drainage of less permeable reservoirs } \\
\text { 6. Expansion of coverage } \\
\text { 7. Applicability in water-flooded pools } \\
\text { 8. Reduction of water surface tension at oil interface } \\
\text { 9. Carbon dioxide breakthroughs in fractures } \\
\text { 10. Project success ratio }\end{array}$ & $\begin{array}{l}0.1 \\
0.2 \\
0.1 \\
0.1 \\
0.1 \\
0.1 \\
0.05 \\
0.05 \\
0.05 \\
0.05\end{array}$ \\
\hline
\end{tabular}

of rocks in wells. This is highlighted as one of the aspects of subsoil use efficiency. Adel Nouara [18] says, "the choice of a drill bit is not exclusively based on ecological factors but takes into account all variable: governmental terms, expenses (cost of drilling, transportation, etc.) alongside with technology sustainability...".

For grouts, the grouting quality and the formation segregation are the equally significant general criteria, which directly characterizes the functional area of the service. Among the partial criteria, the experts equally emphasize the criteria connected with the well bore structure, namely, grout-casing-rocks 
interaction and the stability under higher temperatures and pressures in wells. The highest median values of the general criteria for EOR-change in production output and efficiency period of EOR-are well explainable. As a rule, expenses connected with EOR are rather high. For this reason, technologically, both the increment in hydrocarbon production output and the duration of this increment are important. In return, this is imaged in the increase in the oil recovery factor, which is one of the partial criteria.

It is worthy of mentioning the application of the multi-criteria approaches in the studies performed by Russian scientists [19-22]. For instance, G. I. Krotkov examines efficiency of organizational innovations using an expert survey to evaluate the specific weights of certain indicators by converting qualitative estimates into quantitative estimates of an indicator preference [20]. N. G. Sorokina proposes a two-dimensional matrix of PricewaterhouseCoopers, with determination of strategic and competitive relevance criteria of non-core assets based on expert estimates [21]. E. A. Korolkova uses the system of risk assessment in interaction and self-appraisal of oilfield service companies using the Key Account Identification and Selection Matrix KAISM [22].

The present study authors use the described criteria and their specific weights in development of an express-analysis procedure for technology performance evaluation.

\section{Conclusion}

The international experience shows that oilfield services possess a wide field for operation. Oilfield service companies range from giant Schlumberger, whose divisions provide nine out of 10 products and services, to a single service company like Geolog, specializing in surface data logging for international and offshore drilling projects. Alan Kennedy fairly assumes oilfield services as a "solution-driven industry". This is possible owing to the scientific-and-technical advance, high-technology production, higher professionalization and the related economies of scale [23]. Regarding the Russian experience of interaction between the oil and gas producing and service companies, the present authors emphasize that technology as a project component is underestimated when selecting oilfield development projects. The proposed multicriteria approach to decision-making on a technology and to selection of a provider of drilling fluids, grouts and EOR methods proves the validity of using cost indicators and oil recovery factor equally with parameters of technologies and equipment. The accepted technological decision-making criteria and their specific weights determined using an expert survey will become a framework for the further research aimed to compare technologies by the integral indicator of operation quality.

Reference

1. Available at: https://sudact.ru/law/rasporiazhenie-minprirodyrossii-ot-18052016-n-12-r/metodicheskie-rekomendatsii-popodgotovke-tekhnicheskikh/ (accessed: 05.03.2020).

2. McCreer J. Operational Excellence: Managing Performance in the Oil and Gas Industry. Go beyond benchmarks to decisions and action. 8 p. Available at: https://www.bain.com/ contentassets/38e8df629aee40a1acbed183f979e50c/bain brief_operational_excellence_in_oil_and_gas.pdf/ (accessed: 05.03.2020).
3. Andrukhova O. V., Razmanova S. V. Current state and prospects of domestic oil field services market development. Oil Industry. 2019. No. 6. pp. 9-13.

4. Best available technologies : resource book. Oil Production. Moscow : Byuro NTD, 2017. 273 p.

5. Russian market of oil well drilling : current state and forecast to 2030 : RPI report. Available at: https://rogtecmagazine.com (accessed: 06.08.2019).

6. Husseini T. The future of oil and gas: Eight bold industry predictions. Available at: https://www.offshore-technology.com/ digital-disruption/blockchain/the-future-of-oil-and-gas-predictions/ (accessed: 06.08.2019).

7. Oil and gas well drilling technology : University textbook. In 5 volumes. V. P. Ovchinnikov (Ed.). Tyumen, 2014. 568 p.

8. Dmitriev A. Yu. Basics of oil well drilling technology : teaching aid. Tomsk, 2008. $216 \mathrm{p}$.

9. Rusin L. M., Morozyuk O. A/ Methods of enhanced oil recovery (theory and practice) : teaching aid. Ukhta, 2014. 127 p.

10. Shlyapentokh V. E. E. Problems of the quality of sociological information: validity, representativeness, prognostic potential.

11. Litvak B. G. Experts' estimates and decision-making. Moscow : Patent, 1996. $271 \mathrm{p}$.

12. The construction and use of expert surveys in the social sciences. Available at: https://www.v-dem.net/files/2/IPSA\%20 expert\%20survey\%20panel\%20Call\%20for\%20Papers.pdf (accessed: 06.08.2019).

13. Volkova I. I. Methods for studying drilling processes based on oilfield data processing (in terms of the Timan-Pechora oi province): thesis of inauguration of Dissertation ... of Candidate of Engineering Sciences. Ukhta, 2000. 150 p.

14. Theory of statistics : textbook. By Ed. G. L. Gromyko. 2nd Ed. Revised and enlarged. Moscow : INFRA-M, 2005. 476 p.

15. Sidorenko E. V. Methods of mathematical processing in psychology. Saint-Petersburg : Rech, 2000. 350 p.

16. Bondarchuk S. S., Bondarchuk I. S. Statistical processing of experimental data in MS Excel : teaching aid. Tomsk, 2018. $433 p$.

17. Romashkina G. F, Tatarova G. G. Coefficient of concordance in the analysis of sociological data. Sociologiya: 4M. 2005. No. 20. pp. 131-157.

18. Nouara A. Development of Performance Measurement Model for Oil Operations: A Study of Libyan Oil Companies. A Thesis Submitted for the Degree of Doctor of Philosophy. Brunel University London United Kingdom. April 2015. 274 p.

19. Muslina G. R., Pravikov Yu. M. Methods of cost-effectiveness analysis of technologies and equipment : teaching aid. Ulyanovsk, 2017. $101 \mathrm{p}$.

20. Krotkov G. I. Integrated oestimation of corporate restructuring in oilfield services (in terms of Tatneft) : thesis of inauguration of Dissertation ... of Candidate of Economic Sciences. Moscow, 2012. $27 \mathrm{p}$.

21. Sorokina N. G. Implementation mechanisms of outsourcing in industry : thesis of inauguration of Dissertation ... of Candidate of Economic Sciences. Orenburg, 2008. 22 p.

22. Korolkova E. A. Risk assessment and redistribution in oilfield service production activities : thesis of inauguration of Dissertation ... of Candidate of Economic Sciences. Tyumen, 2009. $24 \mathrm{p}$.

23. Unsung workhorses of the oil industry. Oilfield Services Companies. KPMG Global Energy Institute. Annual report 24 p. Available at: https://assets.kpmg/content/dam/kpmg/ pdf/2016/03/oilfield-services-companies-unsung-workhorses-oil-industry.pdf (accessed: 06.08.2019). 